\title{
NEW THEORY OF EVOLUTION FROM GENETIC COMPLEXITY OF DIVERSE PERSPECTIVES
}

\author{
Y. V. Subba Rao ${ }^{1 \bowtie(D)}$ \\ ${ }^{1}$ Executive Engineer (Retired), University Science and Instrumentation Centre, Sri Venkateswara University, \\ Tirupati, Andhra Pradesh State, India.
}

\section{ABSTRACT}

In this study, a new hypothesis of evolution is proposed. Genetic complexity offers a plausible scenario for the evolution of life on Earth and there is ample evidence from different perspectives supporting it. The current theory of evolution and natural selection proposed by Darwin is accepted in biology, plausibly, for want of a more viable alternative in based on the recent advances made in cell biology, molecular biology, and genetics. The proposed hypothesis of evolution based on the different perspectives of genetic complexity addresses the two critical areas of advanced complex life of Cambrian explosion and the development of even more complex and intricate human brain in contradistinction to the Evolution Theory envisaged by Charles Darwin.

Received 14 September 2021

Accepted 14 October 2021

Published 31 October 2021

CorrespondingAuthor

Y. V. Subba Rao,

yvsubbarao2004@yahoo.com

DOI

10.29121/granthaalayah.v9.i10.2021 .4316

Funding: This research received no specific grant from any funding agency in the public, commercial, or not-for-profit sectors.

Copyright: (C) 2021 The Author(s). This is an open access article distributed under the terms of the Creative Commons Attribution License, which permits unrestricted use, distribution, and reproduction in any medium, provided the original author and source are credited.

Keywords: Theory, Complexity of Diverse, Genetic, Earth

\section{INTRODUCTION}

The current Theory of Evolution envisaged by Darwin moved from a pivotal role in origin and evolution of life to an outcast from mainstream thinking into a theory in crisis in view of advances made in the fields of biology as well as astronomy over the past five decades of irreducibly complex systems on the cellular level.

Wald Wassermann contends that scientists still don't agree on the definition of 'life' https://www.goodreads.com/author/quotes/18998740. Origin of life is ancillary to Evolution. Science has not unravelled the mystery yet. Experiments on amino-acids found in meteorites have only indicated the body which sis necessary to hold life but not the spirit which gives life to the body. Spirit and its role in the origin of life is the 'Vedic Thought'. Science and religion always coexist.

\subsection{GENETIC VARIATION AND ITS ORIGINS}

Recent researches hint at multidisciplinary approach to understand the genetic complexity of life. DNA arose simultaneously with the origin of lifeFrancis Crick (1988). In 1935, Dobzhansky discovered the DNA structure. Now, the function of genes and the way they are organized as well as the human genetic diversity. He stated that human diversity is not singly a biological process but a blend of 'biology and culture.'

\section{EXAMINING DARWIN'S EVOLUTIONARY THEORY}

'Natural selection' produces nothing. It can only "select" from possible genetic variations of the survival value of what is born; biological variations may occur in nature, but natural selection is not possible. Natural selection only 
operates once there is life and reproduction and not earlier.

Scientists disagree to recognize the relationship of 15 to 20 different species of early humans some of which are extinct. Many earlier human species have left no living descendants. How far Darwin is right to be acceptable when he states that man is the modified descendant of some pre-existing form. Human beings have a heart and brain, the two most complex organs in their system. The eye, and the ear are other examples of irreducible complexity. The eye possesses inimitable contrivances for adjusting the focus, accommodating power to varying amounts of light, and ability for the optical error corrections and saccadic movements, etc. Every individual part is integral. These aspects have never been considered by Darwin. To consider them to have been formed step by step by 'natural selection', which Charles Darwin himself confessed, is absurd in the highest degree.

The family tree analogy provides that the two organisms, Hominids along one branch and ape species along another branch which are similar does not provide a common ancestor. It is well known that humans and chimps have 98-99\% identical DNA. Chimpanzees have 24 pairs of chromosomes and humans have 23 , there are many significant differences, it is at least roughly 125 million $\left(1.25 \times 10^{8}\right)$ DNA base pairs that are different between the two species. It has been shown herein, in the section on 'Origin of Life', that the number of DNA entries required to differentiate one individual from the other is $3 \times 10^{6}$ Subba Rao and Ramana Rao (2017).

There is a battle going on between two schools of thought over the hearts and minds of people. One side advocate that humans are just animals, the product of millions of years of random mutations. The other side strongly affirms what the different religions hold in that man is unique and appeared on earth as such with heart and mind. There can never be two views more diametrically opposed to each other than these two. Darwin's Theory of Evolution could not be sustained as a continuous process since no evolution took place after the appearance of Human in so far as no change in form is noticed since the advent of human about 2.5 million years ago. Darwin might have known that evolution of human into divinity is also included when he said that evolution is a continuous process of change in quality of life from the stage of appearance of human being from primitive level or stone-age man to a man bordering on divinity attaining higher transcendental consciousness. We need to respect and regard this great genius who set into motion scientific thinking about the origins and development of life and not disturb him in his grave. We shall now consider how evolution of life on earth of all living beings, including human beings, has been made possible.

Only that which exists can evolve. Darwinism is often mistaken for his theory of evolution that pre-existing species give rise to modified ones gradually It suggests as one of the possible explanations for given moments in the evolutionary process. Evolution is an event supported by many elements but a satisfactory explanation of the mechanisms underlying it has not been found yet.

Darwin's concept that all mammals and all single celled organisms are related because they are produced by the 'common ancestor'. As per the two concepts, 'common ancestor' and 'tree analogy', all the species living on earth must be true to this proposition which means the branches in turn become trunks for evolution different species looks absurd.

\section{GENETIC COMPLEXITY}

L. L. Cavalli-Sforza after investigating the 'gene frequency distributions' concluded that the information of all DNA sequences containing protein-encoding genes, both nuclear and mitochondrial, as well as microsatellite has accumulated 
exponentially Luigi (2019). Alexei Sharov and his mate Richard Gordon have also corroborated this view Gordon and Sharov (2013). It means that life evolved with exponentially increased complexity similar to Moore's law https://www.webopedia.com/definitions/moores/ which incidentally is found to be true from Hindu Cosmology Subba Rao and Ramana Rao (2017).

Robert Shapiro (1986) that in the event of failure of all chemical experiments about the origin of life and when new geological evidences make a sudden appearance of life on the earth and when life is not found elsewhere in the universe, it may be that scientists might take recourse to religion for solution, that he would stick to existing scientific explanations Robert Shapiro (1986).

In contradistinction to the statement of Robert Shaprio, any scientist can rightly search religion for an answer for a reasonable scientific explanation of origin of life as long as that faith is based on science in all its aspects. Hinduism is acknowledged as the greatest of all faiths and has roots of Modern Science by great stalwarts of science evident from their original assertions.

Carl Sagan (1934-1996), Cosmologist and a famous Astrophysicist, states that the existence of the Universe is cyclical with the number of deaths and rebirths and its timescales are longer than the age of the earth or the sun about half the time since 'Big Bang' Carl Sagan (1934-1996), Day and Night of Brahma. The Biblical idea of a few thousand years is not in line with the thinking of Hindus' billions http://astro1.panet.utoledo.edu.

Carl Sagan and Fritj of Capra (1975) noted similarities between the universe age and the Hindu concept of one day duration of Brahma, the Creator Sagan and Capra (1975).

A new theory of evolution emerging from the genetic complexity of different perspectives, namely, Geological Time Scale Periods, Eras and Eons, Cambrian Explosion, Moore's Law in Genetic Complexity, Life cycles of stars, Ten Incarnations in Hinduism, "Jyotish" of Hinduism in contradiction to the "Evolution and natural selection theory" of Darwin is presented here in this paper. Capra, in The Tao of Physics acknowledged the mention of expanding and contracting universe tally with modern cosmology Frifjof Capra (1975).

Stuart J. Inglis, in his book 'Planets, Stars, and Galaxies', wrote that includes periods of time up to 4.32 billion years viz. Dvitiya Parārdha of Śwethavarāha Kalpa. This, interestingly enough, is about the age of the Earth. This is corroborated by the branch of Nuclear Physics from the half-life of the Uranium 238 - Lead 206 process involving a time of 4.5 billion years Stuart (1962).

Professor Arthur Holmes (1895-1965) Geologist, Professor at the University of Durham wrote in his great book, 'The Age of Earth', applauded the ancient Hindus about the precision of the calculation of the age of the earth and the entire universe in their sacred book 'Manusmriti' (source: Hinduism and Scientific Quest - By T. R. R. Iyengar p. 20-21) Holmes (1913).

Alan Watts, a professor, graduate school dean and research fellow of Harvard University, wrote in his several books that the 'Theory of Relativity' is well known to the Hindus practising new states of consciousness and who know the time in billions and 'kalpas' (source: Spiritual Practices of India - By Frederic Spiegelberg Introduction by Alan Watts p. 8-9) Frederic (1962).

Dick Teresi, author and co-author of several books about science and technology, including The God Particle, cofounder of Omni magazine and The Atlantic Monthly credited the Indian Cosmologists as the first to mention the correct age of the earth, the births and deaths of the universe and were knowing even Quantum and Nuclear Physics (source: Lost Discoveries: The Ancient Roots of 
Modern Science - By Dick Teresi p. 159 and 174 -212). For more refer to chapter Advanced Concepts) Dick Teresi (2021).

A new theory of evolution is emerging from the genetic complexity of different perspectives, namely, Geological Time Scale' Periods, Eras and Eons, Cambrian Explosion, Moor's Law in Genetic Complexity, Life cycles of stars, ten incarnations in Hinduism, 'Jyotisj' of Hinduism, disputing the theory of Evolution and Natural Selection of Darwin is presented herein.

\section{DIVERSE PERSPECTIVES ABOUT GENETIC COMPLEXITY}

There are diverse perspectives about genetic complexity. One such is about the Geological Time Scales and the origin of varieties of species as desribed in it including the most complex life of Cambrian Explosion about 520 million years ago. In the same way, when the Moore's Law is applied to understand 'Genetic Complexity' Subba Rao (2021), Gordon and Sharov (2013). Evolution of human life and its proliferation which serves as a bench mark to understand both the origin of life and evolution. Photosynthesis in plants enables us to understand clearly 'what is life' and 'what is evolution'. Likewise, Hinduism which is the most ancient heritage acclaimed as an embodiment of all modern sciences by scientific stalwarts renders a clear idea of origin and evolution of life of all species living on earth.

The ten incarnations of lord Vishnu in Hinduism deciphers the process of evolution. "Jyotish", a Vedānga and ancillary of four Vedas which are as old as the Universe, is the derivative of Astronomy, Astrobiology, Astrophysics and Astrochemistry, deals with the origin and evolution of life. Manusmriti, a sacred text of Hinduism explains the secret of life and energy. All these have been discussed herein to arrive at the correct view of the matter.

\subsection{GENETIC COMPLEXITY: GEOLOGICAL TIME SCALE JUPITER - SATURN ORBITAL SYNCHRONISATION STRUCTURE}

A close observation of the Geologic Time Scale reveals that the timescales namely, Periods, Eras and Eons are multiples of 20,60 and 600 million years' periodicity respectively (YVS.2019) YVS (2021). Also in a similar manner, at regular intervals of approximately 60 million years or multiples of 60 million years, Five Big Mass Extinctions of species occurred. The Ordovician-Silurian Extinction occurred $\sim 444$ million years ago. Late Devonian extinction occurred about 383-359 million years ago. Permian-Triassic extinction happened $\sim 252$ million years ago. TriassicJurassic extinction occurred $\sim 201$ million years' ago. Cretaceous-Paleogene extinction occurred 66 million years ago and Extinction today (Figure 1). 


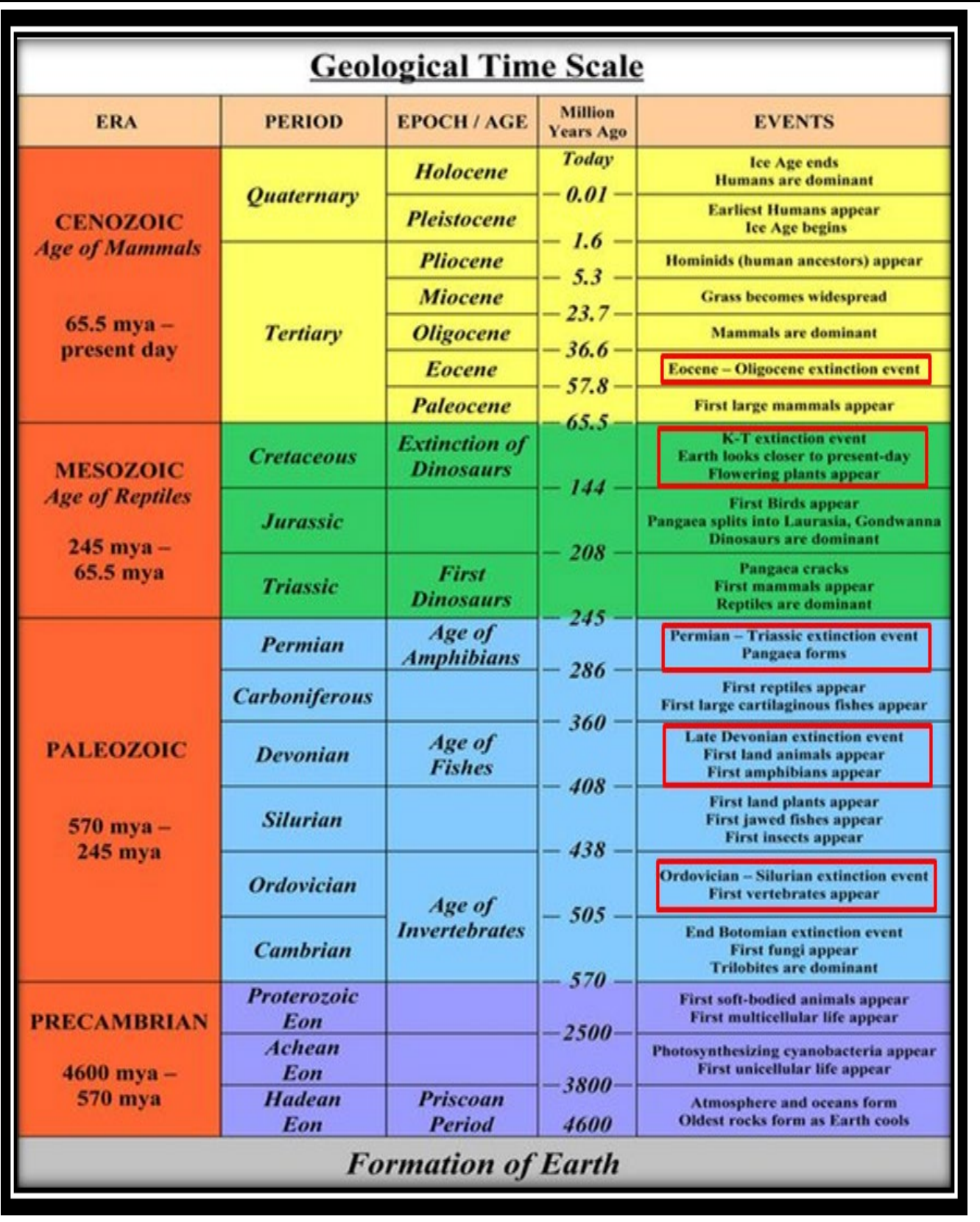

Figure 1 Geological Time Scale

There is other evidence for the coincidence, namely, K-T Boundary 65 million years ago, extinction of the dinosaurs and rise of small mammals) and the now wellestablished 26-million-year periodicity (Galactic Tide-Holmes's cycle) with cometary impacts coinciding with mass extinction events and evolution of all species Napier et al. (2007). This affords a plausible explanation of a striking scientific phenomenon (Figure 2). 


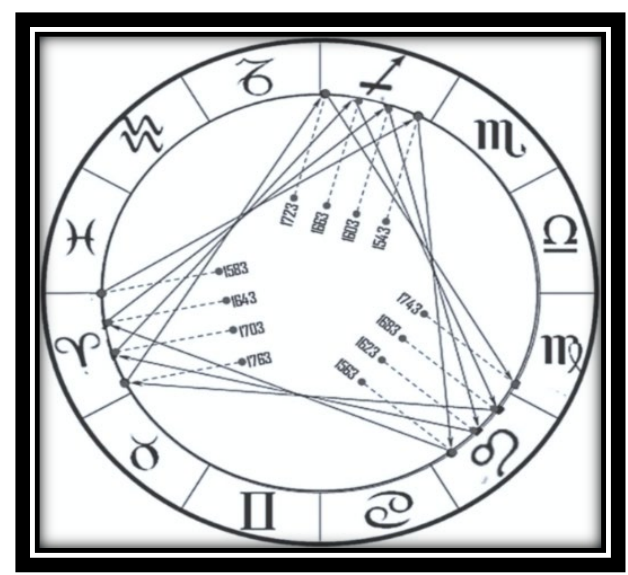

Figure 2 Jupiter and Saturn - Three conjunctions (a trigon) as an Equilateral Triangle

\subsection{CAMBRIAN EXPLOSION}

Mainstream thinking on the Cambrian Explosion, with developments in molecular and cell biology, has given impetus to "Advanced Panspermia Origin of Life". After Cambrian explosion, there appeared suddenly the presently existing phyla of different classes of animals as vertebrates, arachnids and molluscs of animal kingdom. Further, they appeared almost simultaneously from simple to more complex forms. Therefore 'Cambrian explosion' which appeared suddenly with high level of complexity clearly discredits 'Natural Selection' which is based on efflux of time and environmental changes. Therefore, Darwin's 'Natural Selection'. The focus is on Cambrian Explosion of 500 Ma true with Hardy-Weinberg theory https://www.science.gov which corroborates with the orbital resonance of JupiterSaturn (Trigon) whereby the geologic time scales of 'Periods', 'Eras' and 'Eons' are seen to be multiples of $\sim 20 \mathrm{Ma}, \sim 60 \mathrm{Ma}$ and $\sim 600$ Ma respectively.

Similarly, the 'Big Five' extinctions, diversification, evolutionary boundaries are at regular intervals of multiples of $\sim 60 \mathrm{Ma}$ with major changes in climate (Figure 2). Finally, the focus is on the readymade kits of life building blocks contained within meteorites and comets brought to earth from space Callahan (2011).

\section{INCREASE OF GENETIC COMPLEXITY}

Darwin proposed that species with efflux of time can change and give rise to new species from the pre-existing species when a trait is helpful the individual species survive and reproduce and the genetic change is in all probability passed to the next generation which process is known as 'natural selection' and with evolution, its complexity found increased exponentially, similar to Moore's law.

The investigation of gene frequency distributions by Hammer et al. (2019) found that the accumulation of genetic information exponentially encompasses protein-encoding genes, nuclear and mitochondrial, as well as microsatellite and other DNA sequences. Alexei Sharov and Richard Gordon holds the same view about complexity and life. With the evolution of life, its complexity has increased exponentially, similar to Moore's law Alexei (2013) which is found to be true from Hindu Cosmology (YVS, 2021) Rao (2021). 


\subsection{INCREASE OF GENETIC COMPLEXITY AND MOORE'S LAW}

Gordon Moore's (1965) observation that in an integrated circuit (IC), the number of transistors on a microchip double once about every two years. A graph of the logarithm of a function shows an exponential increase of that function (Figure 3). The two researchers, Gordon and Sharov Gordon and Sharov (2013), used Moore's Law and found that life began before the existence of Earth and that genetic complexity doubling every 376 million years. The same approach finally, led them to apply it to biological complexity.

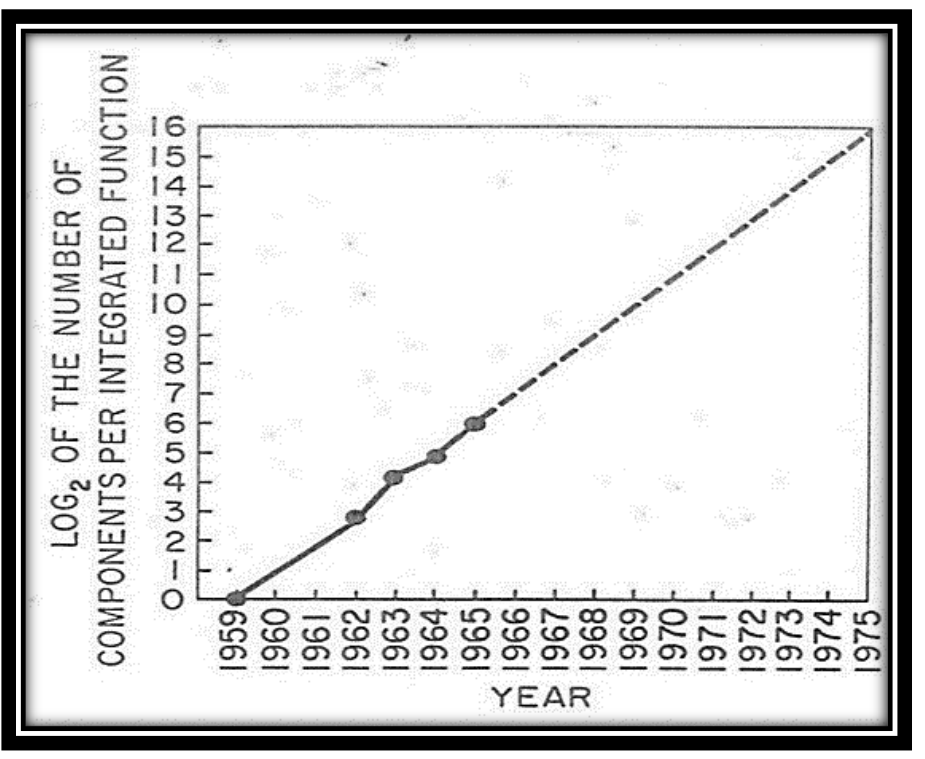

Figure 3 A straight-line graph of the logarithm of a function shows an exponential growth of that function

\subsection{INCREASE OF GENETIC COMPLEXITY AND HINDU COSMOLOGY}

As per Hindu Cosmology creation is cyclic in the universe. As per Bhāgavatam this creation and dissolution of the universe recur once period of 4.32 billion years or 4,320 million years. Life first came into being around 3.6 billion years go. The genetic complexity doubling every 376 million years provides 10 complexities of life like the ten incarnations of Lord Vishnu in Hinduism. Gordon and Sharov states, that life first started about 10 billion years ago Gordon and Sharov(2013), predates the creation of Earth itself is in tune with the Hindu Cosmology that it occurred in the period of activity of immediate previous universe (Figure 4). Hindu Cosmology Corroborates Gordon and Sharov's application of Moore's Law. 


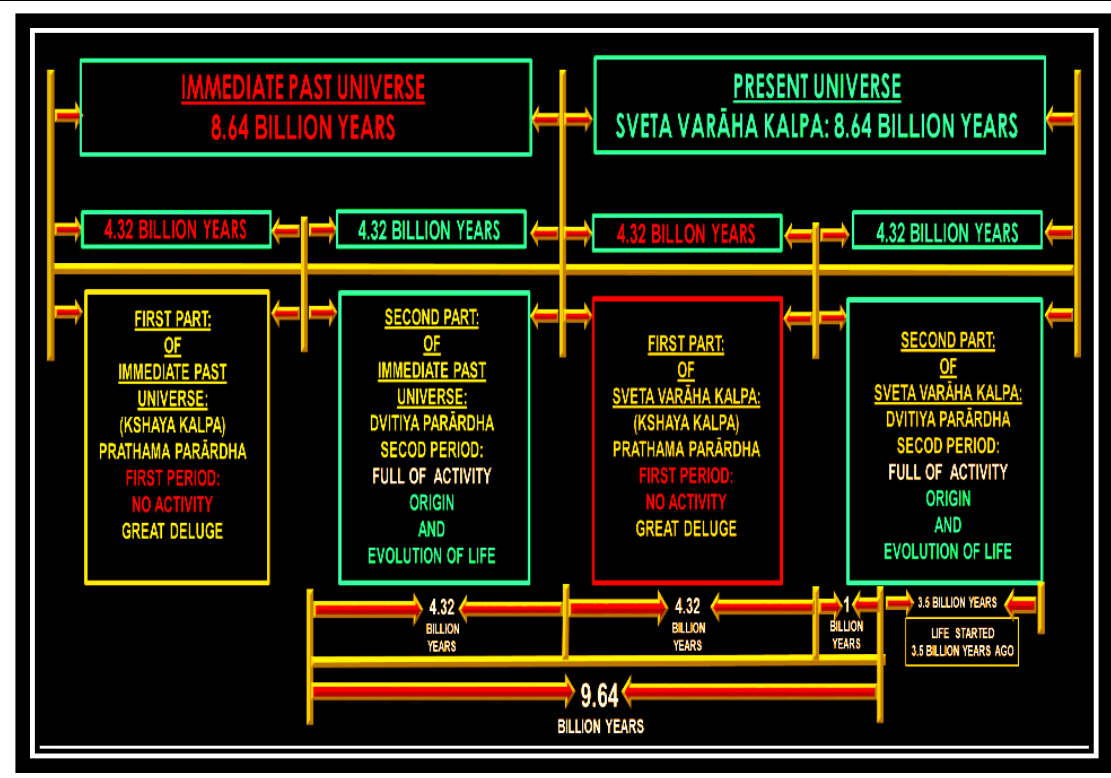

Figure 4 Hindu Cosmology Corroborates Gordon and Sharov's Approach of Moore's Law that Life began 10 billion Years before Earth Existed

\section{GENETIC COMPLEXITY FOUND IN SACRED TEXTS OF HINDUISM ("JYOTISH", “MANUSMRITI", AND “GARUDA PURANA"}

Hinduism excels over all other faiths since its literature runs into a library and not a mere single book as in the case of all other faiths. Its literature mainly divided into two parts, namely, i) "Para Vidya" meaning knowledge of transcendental sciences for evolution of soul, and ii) "Apara Vidya" meaning knowledge of material sciences for ease of living YVS (2021).

\section{1. "JYOTISH"}

"Jyotish", a Vedanga, as old as the age of the Universe, is the study of interaction of electromagnetism with matter YVS (2021). Moon and Mars cause monthly menstruation and copulation, ovulation and fertilisation Sastry (1995), YVS (2017), YVS (2017),Venkata (2019). It establishes Genetic Heredity Subba Rao and Ramana Rao (2017) while affording 'freewill' for evolution of soul towards liberation.

\section{2. "MANUSMRITI"}

The verses of Chapter 1 of Item Nos.1.1, 7, 8, 14 to 20 and 80 of "Manusmriti", a Vedic Text which is self-explanatory and relevant to the present study of the topic Manusmriti (2021).

\section{3. 'LORD VISHNU'S TEN INCARNATIONS' OF “GARUDA PURANA" AND EVOLUTION}

This Purana is named after Garuda because he was the one who first narrated Lord 'Vishnu's Ten Incarnations' to sage Kashyap. and later, from him to others. The ten avatars of Vishnu, the Hindu god of preservation, is referred to as Dashavatara. In order to restore cosmic order, Vishnu is said to descend in form of an avatar. The list of Dashavatara varies across sects and regions. The standard list is: Matsya, Kurma, Vaāha, Narasimha, Vāmana, Parashurāma, Rāma, Krishna, Buddha and Kalki 
The Garuda Purana. Dashāvatāras; sequence is a reflection of popular evolution theory. Monier Monier-Williams appalauded the Hindus as Darwinians and evolutionists centuries earlier to Darwin. Monier-Williams (2014). JBS Haldane (2021) stated that Dashāvatāra gave a "rough idea" of vertebrate evolution:

\subsection{THE DASHĀVATĀRAS ARE EXPLAINED}

Vishnu's ten incarnations are in a definitive order, from simple to more complex life-forms as the reflection of Dashāvatāras as a new and modern evolution theory. Matsya - fish, the first born vertebrates evolved in water; Kurma - tortoise, amphibious Varāha - wild land animal; Narasimha - half-animal and half-human indicative of emergence of animal behaviour of wild nature; Vamana -early dwarf human beings; Parasurāma - early humans dwelling in forests and using weapons; Rāma - humans living in community, beginning of civil society; Balarāma beginning of agriculture signified by plough as his weapon; Krishna - humans practicing animal husbandry, politically advanced societies, humans finding enlightenment; Kalki - advanced humans with great powers of destruction. This interpretation is the precise modern theory of evolution.

\section{THEORY OF EVOLUTION REDEFINED}

At the very outset, it needs to define 'What Is Life?' which is a fundamental question of biology. The selective adaptation of the celestial bodies of the solar system and the 27 lunar constellations (star constellations) in the zodiac lying equidistant along the ecliptic into 'Jyotish' (Vedic Astrology), being one of the six Vedāngas ancillary to the four Vedas of ancient rich heritage of Hinduism for its studies, provides the definition of "life". The celestial bodies cause Sunlight (electromagnetic wave) on earth and interacts with matter (elements) given out by the 27 lunar constellations causing protocells and later transforms into "living cells" with the introduction of the soul (spirit or 'Jivatmaa' (in other words life) initially and thus the soul manifests soul then on. It is straightaway mentioned here that in Jyotish, the Sun is the significator of the soul "(Ātmakāraka)." Atma is kown as Soul, Jivatma is manifested Soul and Jiva is known as Spirit are described in Vedas. Between the living and non-living, the 'Material' is absolutely the same. Living is characterized by 'life' and 'energy' where as it is dormant in non-living. Hinduism holds that 'souls do evolve' from one species to another till it obtains human birth Brihadaranyaka (2015).

The evolution of the species transforming from one species to another is not by efflux of time or by 'natural selection' as contended by Darwin, but it is due to evolution of soul that qualifies the species to evolve from a lower species, with their neural network responding to a lower frequency, to a higher species with their neural network responding to a higher frequency and finally assumes human birth with fundamental frequency of 7.83Hz. (Schumann Frequency). YVS (2021).

All the species respond to the earth's natural resonant harmonic frequency ('Schumann resonance' of $7.83 \mathrm{~Hz}$ ) and evolved during different geological time scale periods over different parts of the globe by selection from genetically possible existing biological variations in nature or environment and which have survival value. On the other hand, human beings, with complex and intricate system, respond fundamentally to the natural harmonic frequency (Schumann Resonane of 7.83Hz) of the Earth arrived only 2 million years' ago and evolved all over the globe, thus, remains unique from all other species. Earth's climate and environment are influenced by synchronized planetary structure of the solar system. The stars give 
out specific elements during their life cycles also relate to the evolution of new species from time to time Seymour (1990).

\section{RESULTS AND DISCUSSION}

- Hindu Cosmology Corroborates Gordon and Sharov's Approach of Moore's Law i.) the idea of doubling of genetic complexity every 376 million years which corroborates with the theory of evolution of ten incarnations of Hinduism and ii) working backwards, they say, that life first came about 10 billion years ago, which of course predates the creation of Earth itself is in tune with the Hindu Cosmology.

- Periods, Eras and Eons of Geological Time Scale as well as Jupiter-Saturn orbital resonance render support to Moor's Law.

- Cambrian Explosion totally disputes Darwinism.

- Hindu Scriptures, namely, 'Manusmriti', Jyotish, Garuda Purana on Ten incarnations support independent evolution of species and not from the 'common ancestor' of Darwinism.

- Theory of Evolution in its Proper Perspective: The theory of evolution is not to be understood as an investigation of the origin of the human being, or for that matter, any of the species, both living and extinct, from preexisting living matter. Evolution of all species on the Earth occur independently. Only the individual organism concerned, including humans, which is on that frequency that is unique to the Frequency of the Earth (Schumann Resonance of $7.83 \mathrm{~Hz}$ ) resonates and tunes to the messages sent out by the earth's magnetic field with a $7.83 \mathrm{~Hz}$ natural frequency pulsation and responds to it just the same way as a radio in homes. The neural network of the organism perceives these planetary magnetic signals, heralding the life Seymour (1990), Percy Seymour (1986) and commence evolution on earth. Evolution is only within the same species of refinement from a rude and rough state to a finer level but not a change of one life form to another life form with efflux of time. This is the correct view is evidenced by the fact that all the species starting from bacteria coexist with the human beings which otherwise would have been extinct.

\section{CONCLUSION}

The results of the study of Genetic Complexity from different perspectives establishes that origin and evolution of the human being, or for that matter, any of the species, both living and extinct, are not from pre-existing living matter. Life gives life and evolution of all species on the Earth occur independently proliferating till the whole earth is filled with population. It is only through evolution of their souls', lower species are reborn as higher species and human being birth is unique in the process of evolution of souls and continue till attaining liberation of soul from the endless death birth cycle utilising his intellect discriminating good from bad, being always positive rather than negative in approach towards all other species, through transcendental consciousness.

\section{ACKNOWLEDGEMENTS}

I would like to acknowledge my son, Professor Y. V. Ramana Rao, M. Tech., Ph. D, Department of Electronics and Communication Engineering, College of 
Engineering, Anna University, Chennai for the careful proofreading of the manuscript and offer of many valuable suggestions.

\section{REFERENCES}

A millennium before Europeans were willing to divest ... - Quotes . Retrieved from https://quotes.yourdictionary.com > author > quote

Alexei Sharov, Richard Gordon (2013) Researchers use Moore's Law to calculate that life began ...18-Apr-2013 - In their paper, Gordon and Sharov take the same approach, ... they say, means that life first came about almost 10 billion years ago, ...

Brihadaranyaka (2015) Upanishad - English translation 10-May-2015 Brihadaranyaka Upanishad is one of the oldest Upanishads and often referred to as the greatest both in substance, length, and theme. Retrieved from https://holybooks.com > brihadaranyaka-upanishad

cambrian evolutionary explosion: Topics by Science.gov. We believe this coincidence is not fortuitous but is consistent with a key prediction of H-W theory whereby major extinction-diversification evolutionary ...https://www.science.gov > topicpages > cambrian+evolu

Callahan (2011). DNA Blocks found in Meteorites. Proceedings of the National Acade. Aug 9,

Carl Sagan (1934-96), Portal: Hinduism/Selected quote/6 - Wikipedia. Retrieved from https://en.wikipedia.org > wiki > Selected_quote

Carl Sagan and Fritjof Capra (1975), have pointed out similarities between the ... much closer to the current known age of the universe than other creation myths.

Day and Night of Brahma. Retrieved from http://astro1.panet.utoledo.edu > ljc > BhagavaGita

Dick Teresi, (2021) Source : Lost Discoveries: The Ancient Roots of Modern Science - By Dick Teresi p. 159 and 174 -212). For more refer to chapter Advanced Concepts

Francis Crick, (1988), In What Mad Pursuit: A Personal View of Scientific Discovery (1988), 138.

Frederic Spiegel berg, (1962) Source : Spiritual Practices of India - By Frederic Spiegel berg, Introduction by Alan Watts p.8-9)

Frifjof Capra (1975), The Tao of Physics, pp 198, Shambhala Publications, Inc. 1123 Spruce Street Boulder, Colorado 80302

Gordon and Sharov (2013), Researchers use Moore's Law to calculate that life began ... 18-Apr-2013 - In their paper, Gordon and Sharov take the same approach, only they apply it to ... More information: Life Before Earth, arXiv:1304.3381 ... Retrieved from https://phys.org > Physics > General Physics

Gordon and Sharov(2013) Researchers use Moore's Law to calculate that life began before Earth existed ... In their paper, Gordon and Sharov take the same approach, 18-Apr-2013 - ... Retrieved from https://phys.org > Physics > General Physics

Holmes, Arthur, (1913) (1890-1965) The age of the earth. Harper, London, Call number AER-0386 Digitizing sponsor MSN, Full catalogue record MARCXML and also: Hinduism and Scientific Quest - By T. R. R. Iyengar p. 20-21 


$\begin{array}{lllllll}\text { January } 16, \quad \text { (1998) } & ;\end{array}$
https://www.webopedia.com/definitions/moores/

JBS Haldane (2021) - British scientist without a science degree who made India his home, The Print Profile; 2019 [accessed 18 July 2021]. Retrieved from https://theprint.in >

Luigi Luca Cavalli-Sforza. (2019) 25 January 1922-31 August 2018 Evolutionary trees and genetic drift · by AWF Edwards · 2021 - Fisher will have been the principal intermediary, ... Using as data the gene frequencies of several blood-group ... The Print Profile; [accessed 18 July 2021]. https://royalsocietypublishing.org > doi > rsbm.2020.0015

M. F. Hammer, P. A. Underhill, and L. L. Cavalli-Sforza. (2019) Genomic diversity: applications in human population genetics / edited by Surinder S. ... The Print Profile; [accessed 18 July 2021]. https://link.springer.com > content > pdf

Manusmriti (2021) (Sanskrit text, English translation, Notes and Index) (English, Sanskrit), Publisher : Parimal Publication, ISBN : 9788171105274, 8171105270 Pages : 588

Monier Monier-Williams (2014), Historian Comments. Monier Monier-Williams wrote "Indeed, the Hindus were ... Darwinians centuries before the birth of Darwin, and evolutionists centuries before ... The Print Profile; 2019 [accessed 18 July 2021]. http://www.mysteryofindia.com > 2014/10 > dashavatar

Nabinchandra Sen, (2019) Was evolution ever discussed (perhaps using different terms ... Monier Monier-Williams wrote "Indeed, the Hindus were ... ... Nabinchandra Sen explains the Dashavatara with Darwin's evolution in his Raivatak. The Print Profile ; [accessed 18 July 2021]. https://hsm.stackexchange.com > questions > was-evolut

Percy Seymour, (1986) Cosmic Magnetism, Bristol, U.K.: Adam Hilger.

Rao YVS. (2017) Arcana of the Magus of Lunar Magnetism in the Life of a Native.IJBECS; 3:73-7. Retrieved from https://doi.org/10.11648/j.ijbecs.20170305.14

Rao YVS. (2017) Magus of Astromagnetism. Lambert Academic Publns., West Germany.

Rao, YVS (2021) Stars in the Origin and Evolution of Species: Geological Time Scale Jupiter - Saturn Orbital Synchronisation Structure, International Journal of Research Granthalaya,

Rao, YVS (2021) Stars in the Origin and Evolution of Species: Geological Time Scale Jupiter - Saturn Orbital Synchronisation Structure, Internatrional Journal of Research Granthalaya,

Rao, YVS, (2021) "Definition of Vedic Rao, YVS, Astrology", International Journal of Research - GRANTHAALAYAH 9(3):102-108 DOI:10.29121/granthaalayah. v9. i3.2021.3763. Retrieved from https://doi.org/10.29121/granthaalayah.v9.i3.2021.3763

Rao.YVS (2021), Rich Heritage of Ancient Hindu Wisdom, International Journal of Research, volume 9, pages:240-249. Retrieved from https://doi.org/10.29121/granthaalayah.v9.i5.2021.3946

Gordon and Sharov (2013) Researchers use Moore's Law to calculate that life began ... (18-Apr-2013) - In their paper, Gordon and Sharov take the same approach, ... they say, means that life first came about almost 10 billion years ago, ... https://phys.org > Physics > General Physics 
Richard Gordon and Alexei Sharov (2013) Did life begin before Earth existed? EarthSky 18-Apr-2013 - Geneticists Richard Gordon of the Gulf Specimen Marine Laboratory in Florida and Alexei Sharov of the National Institute on Aging in ... https://earthsky.org > Earth Richard.

Robert Shapiro, (1986) Origins: A Skeptic's Guide to the Origin of Life, page 130 (New York, NY: Summit, (1986).

Sastry P S. (1995) Varāha Mihira's BrihatJataka. New Delhi: Ranjan Publications.

Seymour P, (1990) Astrology: The Evidence of Science. 2nd ed. London: Amazon.

Stuart J. Inglis, (1962), "Planets, Stars and Galaxies, John Wiley \& Sons, New York. Retrieved from https://doi.org/10.1119/1.1941917

Subba Rao, Y. V. (2021). Human DNA Replicates Solar System European Journal of Applied Sciences: 9(5), 66-82. Retrieved from https://doi.org/10.14738/aivp.95.10877

Subba Rao, Y. V. (2021). Human DNA Replicates Solar System. European Journal of Applied Sciences, 9(5), 66-8. Retrieved from https://doi.org/10.14738/aivp.95.10877

Subhash Kak (2021) Source : The Wishing Tree - By Subhash Kak p. 75 - 77

The Garuda Purana - Complete Text - Hinduwebsite.com Garuda Purana is one of the Vishnu Purunas. ... The Hindu concept of heaven and hell described in this scripture has some similarities with the descriptions of ...https://www.hinduwebsite.com > sacredscripts > puranas

Venkata Subba Rao Yeragudipati. (2019) Lunar Magnetism Orchestrates Menstrual Cycle in Symphony of Life. AJBLS ; 7: 104-9. Retrieved from https://doi.org/10.11648/j.ajbls.20190705.12

William Napier, J.T. Wickramasinghe, Nalin Chandra Wickramasinghe (2007) The origin of life in comets October DOI :10.1017/S1473550407003941

Y. V. Subba Rao, (2021) European Journal of Applied Sciences. View Vol. 9 No. 5 (2021): European ... Human DNA Replicates Solar System. Y. V. Subba Rao. 66-82. https://journals.scholarpublishing.org > index.php > AIVP. Retrieved from https://doi.org/10.14738/aivp.95.10877

Y. V. Subba Rao, Y. V. Ramana Rao, (2017) DNA Finger Printing and Horoscopy for Determining Paternity or Maternity of a Child, Mathematics Letters. Vol. 3, No. 5, p. 53-57. $\quad$ Retrieved from https://doi.org/10.11648/j.ml.20170305.13

Y. V. Subba Rao, Y. V. Ramana Rao, (2017) DNA Finger Printing and Horoscopy for Determining Paternity or Maternity of a Child, Mathematics Letters. Vol. 3, No. 5, p. 53-57. Retrieved from https://doi.org/10.11648/j.ml.20170305.13

https://www.goodreads.com/author/quotes/18998740.Wald_Wassermann ? page $=5$ Wald Wassermann $>$ Quotes 